\title{
Birds of a high-altitude cloud forest in Alta Verapaz, Guatemala
}

Knut Eisermann ${ }^{1} \&$ Ulrich Schulz

University of Applied Sciences Eberswalde, Fr. Ebertstr. 28, 16225 Eberswalde, Germany.

1 Current address and address of correspondence: Knut Eisermann. P.O. Box 098 Periférico. Guatemala, Ciudad

Guatemala, Centroamérica. Tel.: 502-5906 6479; knut.eisermann@proeval-raxmu.org

Received 03-III-2005. Corrected 18-VII-2005. Accepted 28-VII-2005.

\begin{abstract}
The Northern Central American Highlands have been recognized as endemic bird area, but little is known about bird communities in Guatemalan cloud forests. From 1997 to 2001 a total of 142 bird species were recorded between 2000 and 2400 masl in cloud forest and agricultural clearings on Montaña Caquipec (Alta Verapaz, Guatemala). The bird community is described based on line transect counts within the forest. Pooling census data from undisturbed and disturbed forest, the Gray-breasted Wood-Wren (Henicorhina leucophrys) was found to be the most abundant species, followed in descending order by the Common BushTanager (Chlorospingus ophthalmicus), the Paltry Tyrannulet (Zimmerius vilissimus), the Yellowish Flycatcher (Empidonax flavescens), the Ruddy-capped Nightingale-Thrush (Catharus frantzii), and the Amethyst-throated Hummingbird (Lampornis amethystinus). Bird communities in undisturbed and disturbed forest were found to be similar (Sørensen similarity index 0.85), indicating low human impact. Of all recorded species, $27 \%$ were Nearctic-Neotropical migratory birds. The most abundant one was the Wilson's Warbler (Wilsonia pusilla). The Montaña Caquipec is an important area for bird conservation, which is indicated by the presence of four species listed in the IUCN Red List (Highland Guan Penelopina nigra, Resplendent Quetzal Pharomachrus mocinno, Pink-headed Warbler Ergaticus versicolor, Golden-cheeked Warbler Dendroica chrysoparia), and 42 Mesoamerican endemics, of which 14 species are endemic to the Central American Highlands. The results presented here will be useful as baseline data for a long-term monitoring. Rev. Biol. Trop. 53(3-4): 577-594. Epub 2005 Oct 3.
\end{abstract}

Key words: Bird community, cloud forest, conservation, Guatemala, Nearctic-Neotropical migrants, species richness.

Tropical rainforests have been labeled as some of the most endangered biomes on a global scale (Dobson 1996). While public interest is mainly focused on lowland rainforests (Wilson 1992, Primack 1993, Dobson 1996, Primack and Corlett 2005), the overall area of cloud forests in the world has been more greatly reduced than lowland forests in the last few decades (Doumenge et al. 1995, Hamilton et al. 1995). Between 1990 and 2000, Guatemala had an annual deforestation rate of $1.7 \%$ of remaining forests, equaling $485 \mathrm{~km}^{2}$ (FAO 2003).

Humid broadleaf forests within the condensation zone, which is usually above $1000 \mathrm{~m}$, are known as cloud forests (Richards 1996,
Brown and Kappelle 2001). Characteristic northern Mesoamerican cloud forest birds, like the Resplendent Quetzal (Pharomachrus mocinno) and the Slate-colored Solitaire (Myadestes unicolor), range in altitude from $\sim 1000$ $3000 \mathrm{~m}$. At the lower range limit, these species are associated with many lowland rainforest species with an upper range limit at 1500-1 $800 \mathrm{~m}$ (Howell and Webb 1995). High species turnover rates have been observed along an altitudinal transect in the Sierra Madre (Navarro 1992), and there is almost no similarity in bird species composition between lowland broadleaf forests and cloud forests above $2000 \mathrm{~m}$ (pers. obs.), which can therefore be considered as the habitat of cloud forest specialists. 
Although the Guatemalan highlands have previously been included in an endemic bird area (Bibby et al. 1992b, Long 1995, Wege and Long 1995, Stattersfield et al. 1998), there is no comprehensive description of bird communities widely available. This study was carried out as a thesis research (Eisermann 1999) and aims to increase the knowledge on the structure of bird communities in high-altitude cloud forests in Guatemala.

In order to decrease human impact on the cloud forest, local conservation institutions provide agricultural support and alternative income opportunities to the local people (Schulz and Unger 2000). Birds have been used as indicators for the effectiveness of conservation efforts in biomonitoring programs (Kremen et al. 1994). In order to measure the impact of the efforts of several conservation institutions at Caquipec, a long-term monitoring program of the avifauna will be implemented based on the results of this study.

\section{MATERIALS AND METHODS}

\section{Study area}

The Montaña Caquipec $\left(15^{\circ} 23^{\prime} \mathrm{N}, 90^{\circ} 11^{\prime} \mathrm{W}\right)$ is a karst mountain (Weyl 1980) which is characterized by a rugged topography, located $\sim 45 \mathrm{~km}$ southeast of the city of Cobán, department Alta Verapaz. The study area includes cloud forest and open agricultural habitats, at elevation of $2000-2400 \mathrm{~m}$.

The area is often enveloped in clouds with an annual precipitation of $\sim 4000 \mathrm{~mm}$ and a mean annual temperature of $15^{\circ} \mathrm{C}$ (MAGA 2002). Primary vegetation is an evergreen humid broadleaf forest, with canopy heights between 25 and $40 \mathrm{~m}$. The tree community is species rich, including different species of the laurel family (Lauraceae), oaks (Quercus spp.), and yellowwood (Podocarpus sp.). The forest canopy on ridges is dominated by oaks (Quercus spp.). A low-canopy (5 m) elfin forest (Cavendishia sp. and other Ericaceae) is found in small patches on ridges most exposed to wind. Treeferns (Dicksoniaceae and Cyathaceae), various shrubs (e.g. Gesneriaceae, Melastomataceae) and small palms (Chamaedorea spp.) dominate the forest understory in most areas. Due to the high humidity in the forest, most of the trunks and branches are heavily covered $(<15 \mathrm{~cm}$ deep) with mosses and liverworts (Bryophyta), ferns (Filicatae), orchids (Orchidaceae), bromeliads (Bromeliaceae) and other epiphytes of the families Ericaceae, Campanulaceae, Piperaceae, and Araceae.

The Montaña Caquipec has been mostly deforested, leaving a remnant forest fragment of $\sim 12 \mathrm{~km}^{2}$ on the least accessible slopes of the mountain peaks. Within this fragment there are clearings of up to 75 ha occupied by small indigenous settlements. The residents of Caquipec belong to the Maya Q'eqchi' ethnic group. They are subsistence farmers who mainly depend on the cultivation of corn (Zea mayz) and beans (Phaseolus sp.) by means of slash-and-burn agriculture. After a few subsequent crop cycles, fields are left fallow for about 5 years, resulting in a large land requirement per farmer. Due to this factor and population increase, the slash-and-burn agricultural methods are unsustainable and have resulted in deforestation of all but the most inaccessible slopes. People live in traditional settlements with simple huts dispersed widely in agricultural clearings. Houses are constructed using the stems of treeferns and timber from the forest. People also use the forest for a variety of subsistence purposes including firewood, hunting, medicinal and edible plants, and tourism. The secondary growth adjacent to cultivated areas is used for cattle raising, the harvest of a sedge (Carex sp.) for roof material, and the fruit of the arrayan-shrub (Myrica cerifera), which is used to produce a natural wax for candles (Schulz and Unger 2000).

The forest appears generally undisturbed, except in some parts where previous timber extraction created an interrupted canopy. Considering birds as highly mobile animals, there is no truly pristine habitat available due to the small size of the remaining forest area. 


\section{Methods}

The bird community of the cloud forest and open habitat was studied for 208 days from September, 1997 to October, 1998.

A definition of terms used in this report follows:

Undisturbed forest: Cloud forest with a closed canopy, without signs of timber extraction.

Disturbed forest: Cloud forest with canopy gaps caused by selective timber extraction for subsistence use.

Open habitat: Agricultural clearings and secondary scrub associated with fallow fields.

Nearctic birds: Nearctic-Neotropical migrants, transient or wintering species which breed in the Nearctic region.

Transient: Nearctic species in the process of migration, present at Caquipec just temporary during the northern winter.

Vagrant: Occasionally observed species, which are resident in the region.

Species nomenclature refers to AOU (1998) and its supplements, names of species treated in this report are affected by Banks et al. (2003, 2004). We treat the Central American form of the Sharp-shinned Hawk (Accipiter striatus chionogaster) separated from the North American form (Accipiter striatus striatus).

Two field methods were applied: casual observations and line-transect counts.

\section{Casual observations}

From September, 1997 to February, 1998 qualitative species composition data were collected using the ad libitum method (Lehner 1978). The principal investigator (KE) walked along existing trails in undisturbed forest, disturbed forest, and open habitat types, between one hour before sunrise until three hours after sunset. Birds were identified by voice or visual signs. The principal investigator was able to familiarize himself with the calls and songs of all resident and migratory bird species during the course of the ad libitum surveys, which was later essential in order to conduct the audio-visual transect counts. During 208 days of field work, a total effort of $1250 \mathrm{hr}$ of survey were conducted throughout the study site. Eight of the 143 species were added to the species list through casual observations made on additional visits from 1999-2001 (Eisermann, pers. observ., P. Kaestner, M. Schweighöfer, R. Haupt, pers. comm.).

\section{Transect counts}

All line-transect sampling was conducted by the principal investigator, between March and August 1998 when favorable weather conditions permitted (no rain, calm). Transect sampling methods followed Bibby et al. (1992a). Nine transects between $200 \mathrm{~m}$ and $900 \mathrm{~m}$ long were flagged on an existing trail network (Fig. 1, Table 1). The total length of all transect lines was $4850 \mathrm{~m}$, of which $3680 \mathrm{~m}$ sampled undisturbed forest and $1170 \mathrm{~m}$ sampled disturbed forest. All individuals seen or heard within a perpendicular distance of $30 \mathrm{~m}$ from the transect line were recorded. Sampling was repeated two to nine times per transect, between 5:30 and 9:00 a.m. The census taker walked at an average speed of $90 \mathrm{~m}$ per $15 \mathrm{~min}$. Total length

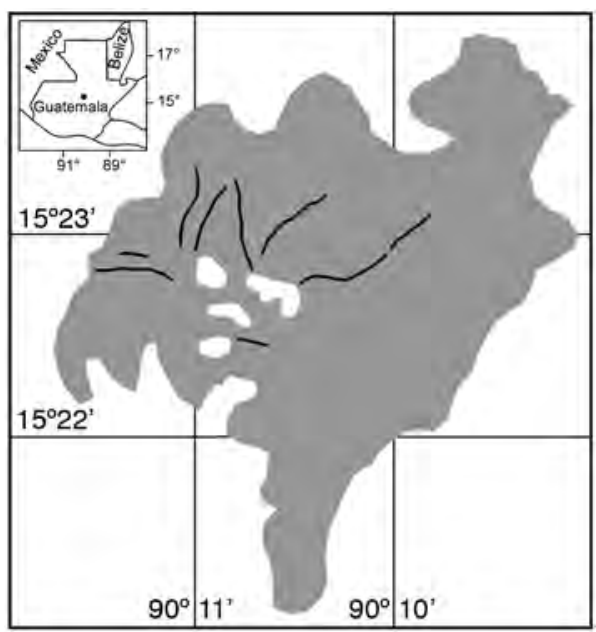

Fig. 1. Location of transects (black lines) within the cloud forest fragment (gray) of the Montaña Caquipec. The inset map shows the location of the study area in Guatemala. 
TABLE 1

Lenght of sampled transects

Transect length in $\mathrm{m}$

Undisturbed forest Disturbed forest

Transect 1
Transect 2
Transect 3
Transect 4
Transect 5
Transect 6
Transect 7
Transect 8
Transect 9
Total

610

$470 \quad 100$

450

$150 \quad 330$

900

750

200

3680

1170

of sampled transects was $31.79 \mathrm{~km}$. Because the effective strip width along the transects was $60 \mathrm{~m}$, the survey design effectively sampled an area of 29.1 ha, representing $\sim 2.4 \%$ of the total forest area. Three of the transects crossed both forest types, but no sampling was conducted within the distance of $50 \mathrm{~m}$ to the habitat edge.

\section{Data Analysis}

\section{Species Richness}

To predict species richness we applied a first-order jackknife estimator to the line transect data (Krebs 1999), using the software "Biodiversity Professional" (McAleece el al. 1997). Each transect was treated as sample unit. Calculation is based on presence/absence. We excluded the records of Nearctic species from this analysis; so the estimate indicates species richness of breeding species only.

\section{Dominance}

To describe the community we calculated dominance ranking using the following equation (modified after Mühlenberg 1993):

$D_{i}=\frac{\bar{n}_{f} \neq 100}{N}$ with $\bar{n}_{i}=\frac{\sum_{t=1}^{n}\left(\frac{n_{i}}{l}\right)_{i}}{t}$ and $N=\sum_{i=1}^{n} n_{t}$

where $D_{i}$ is the dominance of species $i, n_{i}$ is the mean number of individuals of species $i$ per
$100 \mathrm{~m}$ transects (across all transects), $N$ is the sum of all $\bar{n}_{i}, t$ is the number of transects, $l$ is the total length (in $100 \mathrm{~m}$ units) of all counts along one transect.

The relative abundance values used for this analysis were based on the frequency of observation per $100 \mathrm{~m}$ of sampling effort $(\mathrm{n} / 100 \mathrm{~m})$ on the line transects during all months of the survey (March-August). We assumed no significant changes in abundance due to the brief sampling period, which coincided with the peak of reproductive activity.

\section{Abundance}

We compared species abundance between undisturbed and disturbed forest using a permutation test for independent samples based on mean differences. Following Rice (1989) we adapted significance at the alpha level for the multiple comparisons at 0.025 . For these calculations we used the statistical package SSS (Engel 1998). Each transect section representing a particular forest type was used as a replicate unit ( 7 sections in undisturbed and 5 in disturbed forest, Table 1). The same abundance estimate used for the dominance ranking analysis was used for this comparison. In order to describe ß-diversity between open and forest habitats, as well as between undisturbed and disturbed forest, a Sørensen similarity index was calculated based on presence-absence data using the following equation (Magurran 1991):

$$
c_{s}=\frac{2 j}{a+b}
$$

where Cs is the similarity between the two assemblages, $j$ is the number of species occurring in both compared habitats and $a$ and $b$ are the number of species occurring in habitat $a$ and $b$.

\section{RESULTS}

\section{Inventory and species richness}

In the current study, a total of 142 bird species were recorded on Montaña Caquipec 
at elevations between 2000 and $2400 \mathrm{~m}$. Table 2 shows the relative abundance of species obtained from transect counts, and table 3 shows relative abundance values for species which were only recorded during ad libitum sampling. The following bird families were found to be most species rich: Parulidae with 22 species, followed by Tyrannidae (13), Turdidae (12), Trochilidae (9), Emberizidae (8), and Vireonidae with 7 species.

Ninety-three species ( $65 \%)$ were recorded within the cloud forest (undisturbed and disturbed). Subtracting from this total the number of species classified as feeding visitors, vagrants, overhead transients, NearcticNeotropical migrants, and unclassified species, the remaining 60 species are assumed to be local breeders. These are classified as permanent residents, summer residents, or probable altitudinal migrants (Table 2). The predictions of species richness for resident forest-dwelling birds based on transect counts, provided a firstorder jackknife value of 74 species.

\section{Composition and habitat use}

Of 93 species recorded in the cloud forest, $\sim 47 \%$ were insectivores, $\sim 18 \%$ omnivores, $\sim 11 \%$ nectarivores, and $\sim 9 \%$ carnivores. Approximately 40\% (37 of 93) of all species observed in forest (disturbed and undisturbed) were recorded exclusively in this habitat and $\sim 45 \%$ (44 of 98) of the species recorded in open habitat were observed exclusively there. Fifty six species were recorded in the forest and in the open habitat as well. The Sørensen similarity index value comparing the bird community between both forest types combined and open habitat was 0.53 .

The Sørensen-index value comparing undisturbed and disturbed forest was 0.85 , indicating a minor difference in species composition. When comparisons between the two forest types were made using the permutation test, only three species had a significant difference in abundance (Table 2). The total bird abundance of all species was not significantly different between disturbed and undisturbed forest (permutation test, mean differences 3.127, $p=0.10$, based on 792 permutations).

The most abundant species with a dominance $>5 \%$ of the total number of individuals were (in descending order): Graybreasted Wood-Wren (Henicorhina leucophrys), Common Bush-Tanager (Chlorospingus ophthalmicus), Paltry Tyrannulet (Zimmerius vilissimus), Yellowish Flycatcher (Empidonax flavescens), Ruddy-capped Nightingale-Thrush (Catharus frantzii), and Amethyst-throated Hummingbird (Lampornis amethystinus).

\section{Migratory birds}

Approximately a fourth of all recorded species (39 of 143 species, see Table 2 and Table 3) are classified as Nearctic-Neotropical migrants. Nine of these species were observed during the whole migratory season and are considered Nearctic wintering migrants. The remaining 30 Nearctic species are classified as transients. The number of Nearctic-Neotropical migratory species was found to be higher in open habitat than in the forested habitats (Table 4). Tables 2,3 and 4 classify migratory species based on the pattern of presence over one year of sampling. The most abundant wintering Neartic species was the Wilson's Warbler (Wilsonia pusilla), which was recorded from beginning of September until mid-May. The Western Wood-Pewee (Contopus sordidulus) was the only summer resident, recorded from February to July.

\section{Mixed-species flocks}

We observed 30 mixed-species flocks during casual observations and recorded the associated species. Of 93 species recorded for combined forest types, 23 species ( 25\%) were observed foraging in mixed-species flocks (Table 5). Twelve species were wintering or transient Nearctic birds. The number of individuals detected in a single flock ranged from 3 to 30 containing a range of 2 to 6 species. The nucleus species was always the Common Bush-Tanager (Chlorospingus ophthalmicus), no other species 


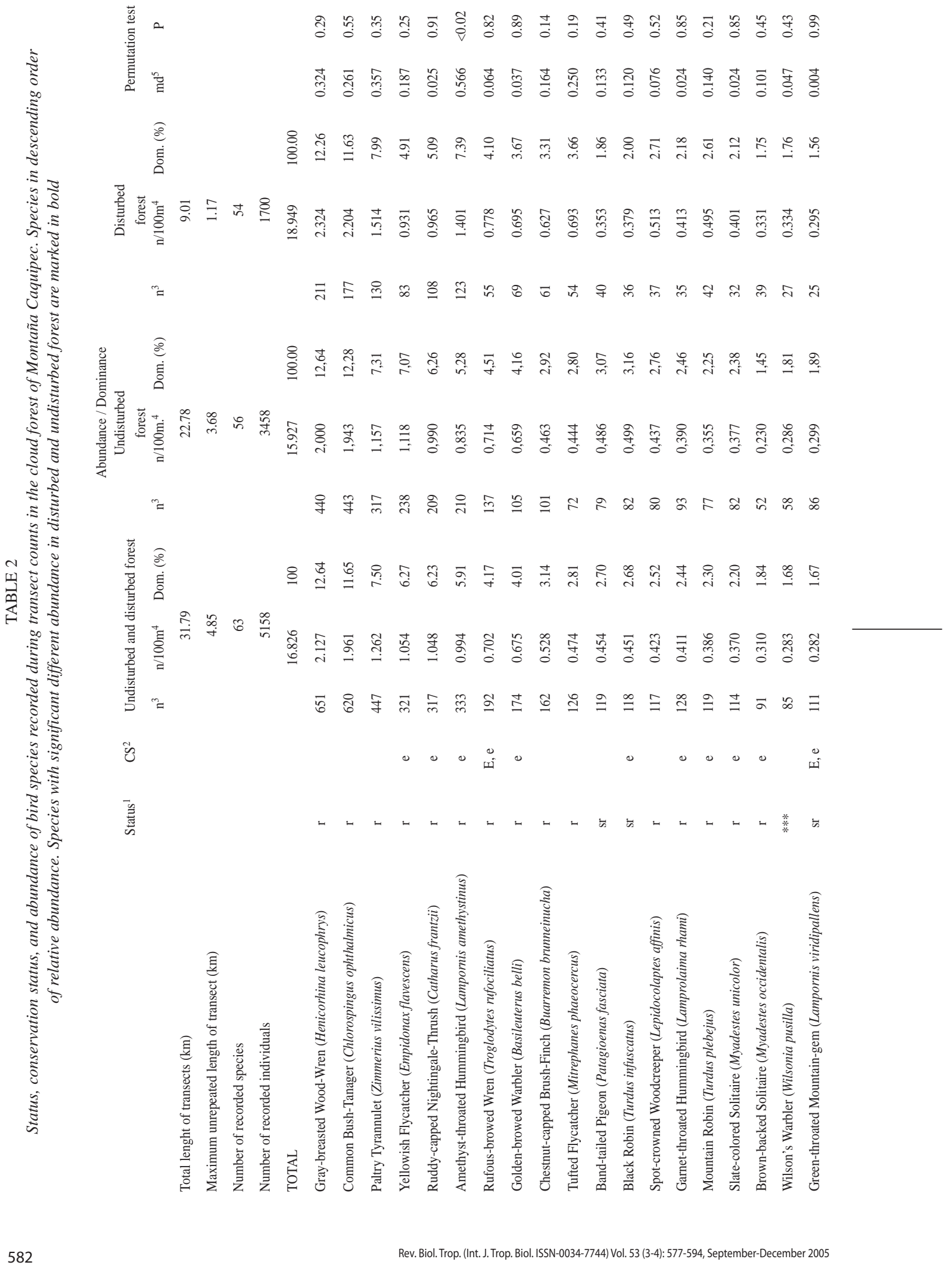




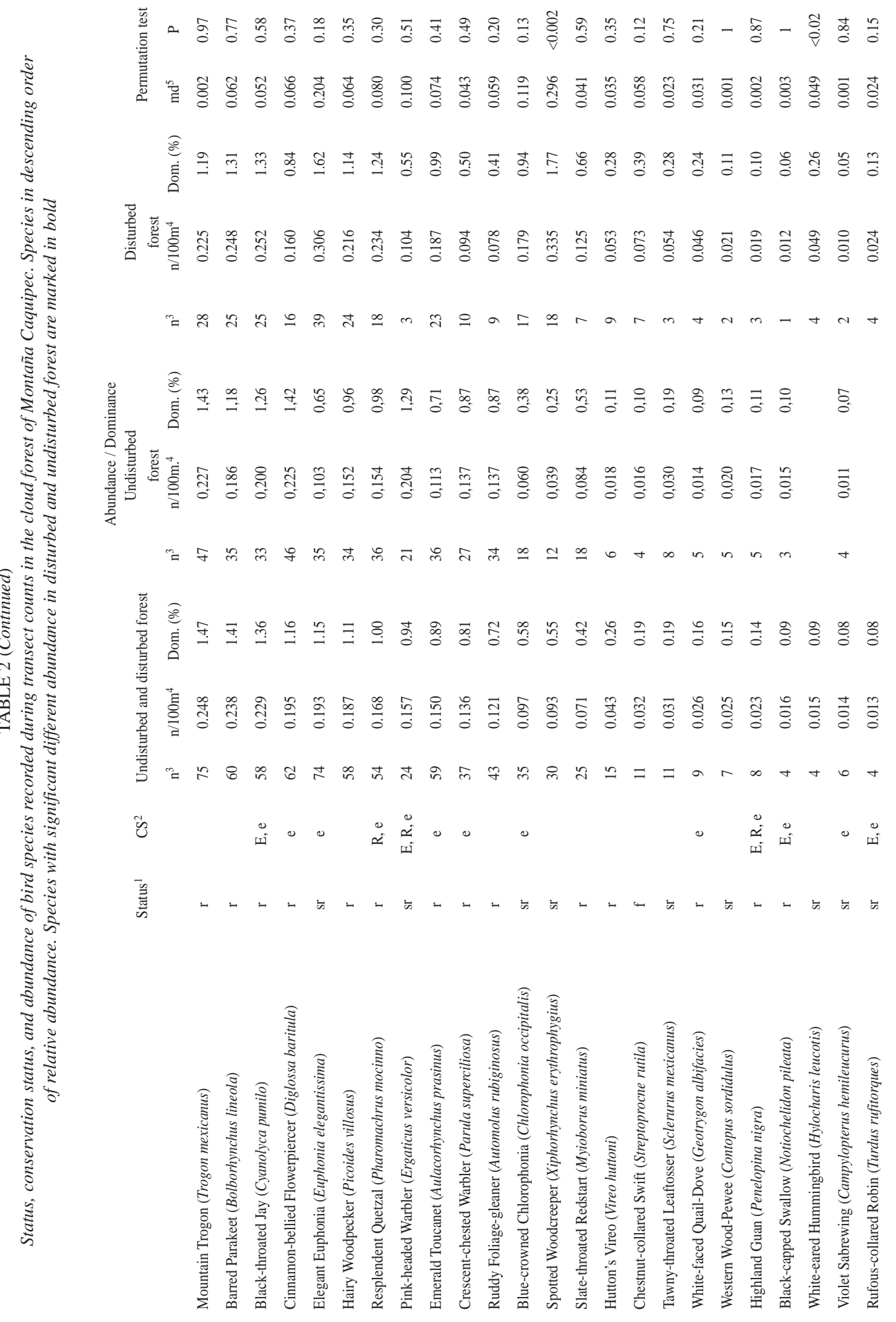




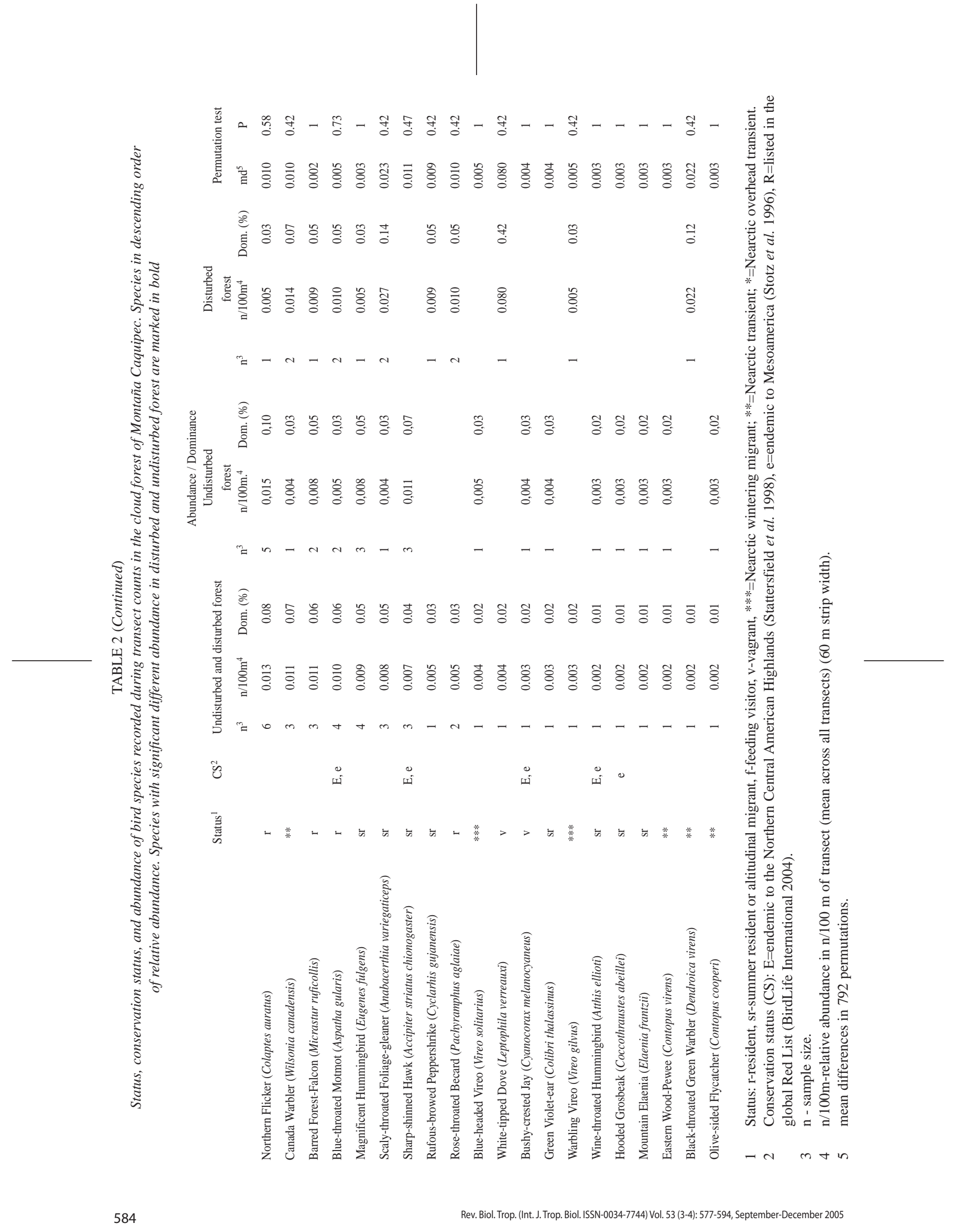


TABLE 3

Status and number of observations of bird species not recorded during transect counts

Number of observations in

Great Blue Heron (Ardea herodias)

Cattle Egret (Bubulcus ibis)

Upland Sandpiper (Bartramia longicauda)

Broad-winged Hawk (Buteo platypterus)

Red-tailed Hawk (Buteo jamaicensis)

Gray Hawk (Asturina nitida)

Hook-billed Kite (Chondrohierax uncinatus)

Sharp-shinned Hawk (Accipiter striatus striatus)

Swallow-tailed Kite (Elanoides forficatus)

American Kestrel (Falco sparverius)

Black Vulture (Coragyps atratus)

Turkey Vulture (Cathartes aura)

Plain Chachalaca (Ortalis vetula)

Buffy-crowned Wood-Partridge (Dendrortyx leucophrys)

Mourning Dove (Zenaida macroura)

Northern Pygmy-Owl (Glaucidium gnoma)

Fulvous Owl (Strix fulvescens)

Mottled Owl (Ciccaba virgata)

Unspotted Saw-whet Owl (Aegolius ridgwayi)

Whip-poor-will (Caprimulgus vociferus)

Black Swift (Cypseloides niger)

White-collared Swift (Streptoprocne zonaris)

Vaux's Swift (Chaetura vauxi)

White-throated Swift (Aeronautes saxatilis)

Sparkling-tailed Hummingbird (Tilmatura dupontii)

Golden-fronted Woodpecker (Melanerpes aurifrons)

Yellow-bellied Sapsucker (Sphyrapicus varius)

White-throated Flycatcher (Empidonax albigularis)

Least Flycatcher (Empidonax minimus )

Hammond's Flycatcher (Empidonax hammondii)

Buff-breasted Flycatcher (Empidonax fulvifrons)

Yellow-bellied Flycatcher (Empidonax flaviventris)

Acadian Flycatcher (Empidonax virescens)

Plumbeous Vireo (Vireo plumbeus)

Brown-capped Vireo (Vireo leucophrys)

Philadelphia Vireo (Vireo philadelphicus)

Tree Swallow (Tachycineta bicolor)

Status ${ }^{1}$

$\mathrm{CS}^{2}$

C

Cloud fores

Openland

Overhead transient

1

$\mathrm{V}$

**

**

**

$\mathrm{r}$

$\mathrm{t}$

v

$*$

$\mathrm{t}$

$\mathrm{t}$

t

t

sr

**

r

r

sr

v

f

?

?
1

2

1

1

1

1

\section{4}

1

$\begin{array}{ccc}\mathrm{e} & & 2 \\ \mathrm{e} & 1 & 4 \\ & & 1 \\ & 1 & 1 \\ \mathrm{E}, \mathrm{e} & >10 & \end{array}$

\begin{tabular}{|c|c|c|}
\hline \multirow[t]{2}{*}{$\mathrm{E}, \mathrm{e}$} & \multicolumn{2}{|l|}{$>10$} \\
\hline & \multicolumn{2}{|l|}{$>10$} \\
\hline e & \multicolumn{2}{|l|}{1} \\
\hline \multirow[t]{5}{*}{$\mathrm{e}$} & $>10$ & $>10$ \\
\hline & 1 flock & 1 flock \\
\hline & \multicolumn{2}{|c|}{$>10$} \\
\hline & \multicolumn{2}{|c|}{1 flock } \\
\hline & \multicolumn{2}{|c|}{1 flock } \\
\hline \multirow[t]{3}{*}{$\mathrm{e}$} & \multicolumn{2}{|l|}{1} \\
\hline & & 1 \\
\hline & \multicolumn{2}{|l|}{7} \\
\hline \multirow[t]{3}{*}{$\mathrm{e}$} & & 1 \\
\hline & & 1 \\
\hline & $>10$ & $>10$ \\
\hline \multirow[t]{7}{*}{$\mathrm{e}$} & & 3 \\
\hline & \multirow[t]{4}{*}{1} & 1 \\
\hline & & 1 \\
\hline & & 1 \\
\hline & & 1 \\
\hline & 3 & 2 \\
\hline & \multicolumn{2}{|c|}{2 flocks } \\
\hline
\end{tabular}


TABLE 3 (Continued)

Status and number of observations of bird species not recorded during transect counts

\begin{tabular}{|c|c|c|c|c|c|}
\hline & \multicolumn{5}{|c|}{ Number of observations in } \\
\hline & Status $^{1}$ & $\mathrm{CS}^{2}$ & Cloud forest & Openland & $\begin{array}{c}\text { Overhead } \\
\text { transient }\end{array}$ \\
\hline Cliff Swallow (Petrochelidon pyrrhonota) & $* *$ & & & & \\
\hline Barn Swallow (Hirundo rustica) & $* *$ & & & & \\
\hline Plain Wren (Thryothorus modestus) & $\mathrm{r}$ & $\mathrm{e}$ & & $>10$ & \\
\hline House Wren (Troglodytes aedon) & $\mathrm{r}$ & & & $>10$ & \\
\hline Eastern Bluebird (Sialia sialis) & $\mathrm{v}$ & & & $>10$ & \\
\hline Orange-billed Nightingale-Thrush (Catharus aurantiirostris) & $\mathrm{r}$ & & & $>10$ & \\
\hline Spotted Nightingale-Thrush (Catharus dryas) & $\mathrm{v}$ & & 1 & & \\
\hline Swainson's Thrush (Catharus ustulatus) & $* *$ & & & 2 & \\
\hline Hermit Thrush (Catharus guttatus) & $* *$ & & & 1 & \\
\hline Clay-colored Robin (Turdus grayi) & $\mathrm{v}$ & & & 1 & \\
\hline Blue-and-white Mockingbird (Melanotis hypoleucus) & $\mathrm{r}$ & $\mathrm{E}, \mathrm{e}$ & & $>10$ & \\
\hline Gray Catbird (Dumetella carolinensis) & $* * *$ & & & 5 & \\
\hline Gray Silky-flycatcher (Ptilogonys cinereus) & $\mathrm{r}$ & & $>10$ & $>10$ & \\
\hline Olive Warbler (Peucedramus taeniatus) & $\mathrm{v}$ & & & 1 & \\
\hline Tennessee Warbler (Vermivora peregrina) & $* *$ & & 3 & 2 & \\
\hline Chestnut-sided Warbler (Dendroica pensylvanica) & $* *$ & & & 1 & \\
\hline Yellow-rumped Warbler (Dendroica coronata) & $* * *$ & & & $>10$ & \\
\hline Townsend's Warbler (Dendroica townsendi) & $* * *$ & & $>10$ & $>10$ & \\
\hline Golden-cheeked Warbler (Dendroica chrysoparia) & $* *$ & $\mathrm{R}$ & 1 & & \\
\hline Hermit Warbler (Dendroica occidentalis) & $* *$ & & & 3 & \\
\hline Blackburnian Warbler (Dendroica fusca) & $* *$ & & 3 & & \\
\hline Black-and-white Warbler (Mniotilta varia) & $* *$ & & 10 & & \\
\hline MacGillivray's Warbler (Oporonis tolmiei) & $* *$ & & & 2 & \\
\hline Red-faced Warbler (Cardellina rubrifrons) & $* *$ & & 1 & & \\
\hline Rufous-capped Warbler (Basileuterus rufifrons) & $\mathrm{v}$ & & & 8 & \\
\hline Gray-crowned Yellowthroat (Geothlypis poliocephala) & $\mathrm{v}$ & $\mathrm{e}$ & & 1 & \\
\hline Northern Waterthrush (Seiurus noveboracensis) & $* *$ & & & 1 & \\
\hline Louisiana Waterthrush (Seiurus motacilla) & $* *$ & & & 3 & \\
\hline Blue-black Grassquit (Volatinia jacarina) & $\mathrm{v}$ & & & 1 & \\
\hline Yellow-faced Grassquit (Tiaris olivaceus) & $\mathrm{sr}$ & & & 4 & \\
\hline White-collared Seedeater (Sporophila torqueola) & $\mathrm{sr}$ & & & $>10$ & \\
\hline White-naped Brush-Finch (Atlapetes albinucha) & $\mathrm{r}$ & & & $>10$ & \\
\hline Lincoln’s Sparrow (Melospiza lincolnii) & $* *$ & & & 1 & \\
\hline Rufous-collared Sparrow (Zonotrichia capensis) & $\mathrm{r}$ & & & $>10$ & \\
\hline Rusty Sparrow (Aimophila rufescens) & $\mathrm{v}$ & e & & 1 & \\
\hline Grayish Saltator (Saltator coerulescens) & $\mathrm{v}$ & & & 1 & \\
\hline Rose-breasted Grosbeak (Pheucticus ludovicianus) & $* *$ & & & 3 & \\
\hline
\end{tabular}


TABLE 3 (Continued)

Status and number of observations of bird species not recorded during transect counts

Number of observations in

$\begin{array}{llll}\text { Status }^{1} & \text { CS }^{2} \quad \text { Cloud forest } & \text { Openland } & \begin{array}{c}\text { Overhead } \\ \text { transient }\end{array}\end{array}$

Great-tailed Grackle (Quiscalus mexicanus)

Melodious Blackbird (Dives dives)

Yellow-backed Oriole (Icterus chrysater)

Baltimore Oriole (Icterus galbula)

Black-capped Siskin (Carduelis atriceps)

Black-headed Siskin (Carduelis notata)

$\begin{array}{ccc}\mathrm{r} & & >10 \\ \mathrm{v} & \mathrm{e} & 1 \\ \mathrm{v} & & 3 \\ * * & & 1 \\ \mathrm{v} & \mathrm{E}, \mathrm{e} & 2 \\ \mathrm{sr} & & >10\end{array}$

1 Status: r-resident, sr-summer resident or altitudinal migrant, f-feeding visitor, v-vagrant, t-overhead transient, ?-status unknown, $* * *=$ Nearctic wintering migrant; $* *=$ Nearctic transient or vagrant; *=Nearctic overhead transient.

2 Conservational status (CS): E=endemic to the Northern Central American Highlands (Stattersfield et al. 1996); $\mathrm{e}=$ endemic to Mesoamerica (Stotz et al. 1996), $\mathrm{R}=$ listed in the global Red List (BirdLife International 2004).

TABLE 4

Status of bird species recorded in Caquipec from 1997-2001 ${ }^{1}$

Study area $\quad$ Forest of species

Neotropical species $(\mathrm{n}=101)$ :

Permanent resident (recorded during the whole year)

$\begin{array}{ccc}45 & 38 & 29 \\ 26 & 22 & 17 \\ 2 & 2 & 2 \\ 23 & 7 & 18 \\ 5 & - & - \\ & & \\ 9 & 7 & 8 \\ 27 & 14 & 21 \\ 3 & - & - \\ 3 & 3 & 3 \\ 143 & 93 & 98\end{array}$

TOTAL

98

1 Classification of Neotropical and Nearctic species according to Howell and Webb (1995) and DeGraaf and Rappole (1995), subclassifications using the author's observations. Resident and Nearctic form of Sharp-shinned Hawk (Accipiter striatus chionogaster and A. s. striatus) are listed separately. 
TABLE 5

Bird species observed in mixed-species foraging flocks

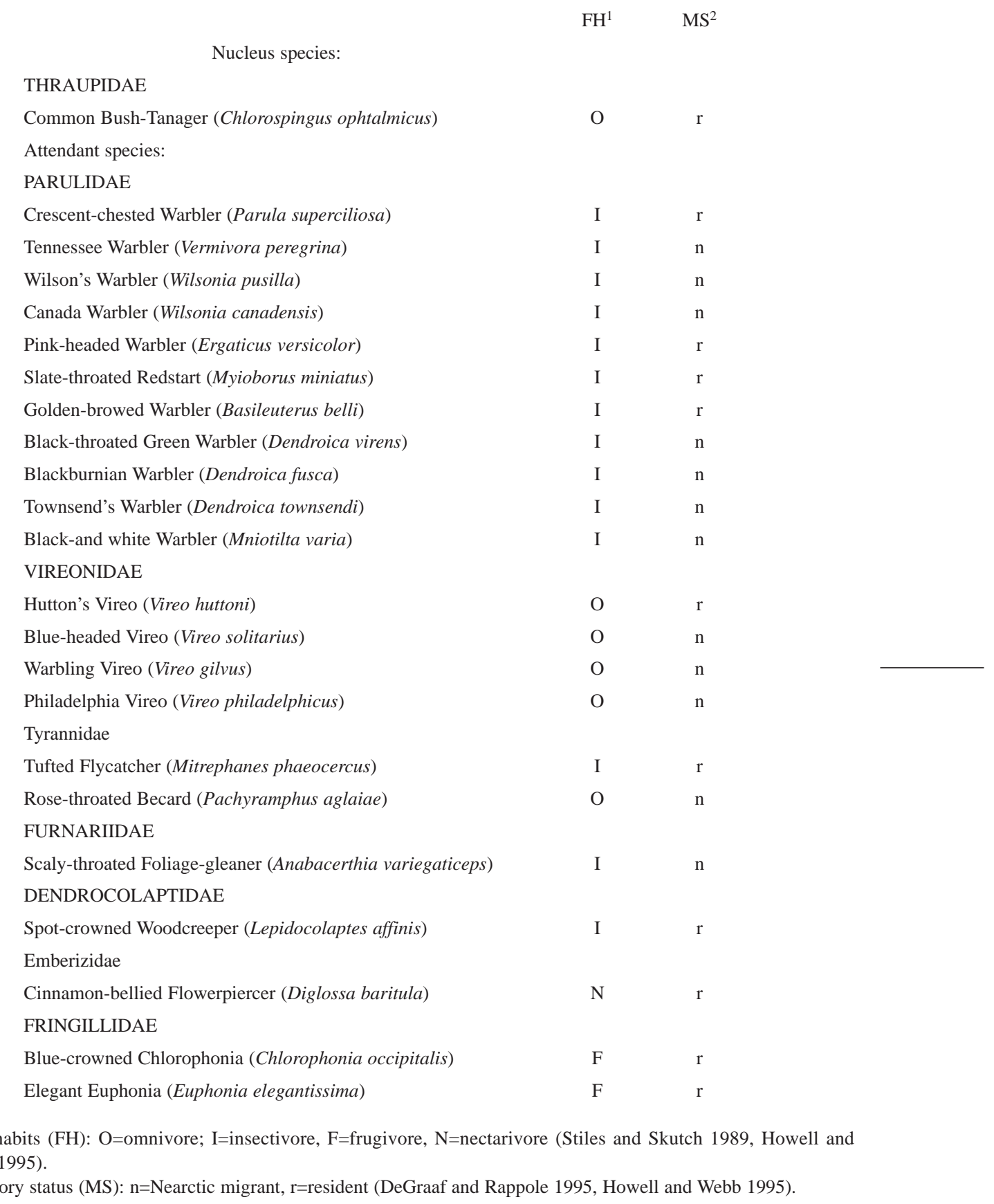

Webb 1995)

2 Migratory status (MS): $n=$ Nearctic migrant, $r=$ resident (DeGraaf and Rappole 1995, Howell and Webb 1995). 
was present in all flocks. Adjoining species were observed in all forest strata.

\section{DISCUSSION}

\section{Inventory and species richness}

Species richness depends on various ecological factors. In general, it decreases with increasing latitude and altitude (Begon et al. 1990). Terborgh (1977) found a peak in species richness at the elevation of $1500 \mathrm{~m}$ along an altitudinal transect on the eastern slope of the Peruvian Andes, where species richness decreased above this elevation. Navarro (1992) recorded a declining species richness from $680 \mathrm{~m}$ to $3100 \mathrm{~m}$ in the Sierra Madre, Mexico. Therefore we expected species richness at Caquipec (>2 $000 \mathrm{~m}$ ) would be lower compared to species richness values of $\sim 100$ resident species recorded locally in undisturbed cloud forest at $1500 \mathrm{~m}$ (Eisermann, unpub. data). In the current study we predicted a species richness of 74 species with jackknife estimator, which is 14 species more than we obtained from transect counts and casual observations (60 species). Although the species accumulation curve from transect counts indicates that almost all species were detected (Fig. 2), several rare or vagrant species may be expected to contribute to species richness.

\section{Comparison with other cloud forest avifaunas}

The distribution of cloud forest species in northern Central America is known on a large scale (Howell and Webb 1995), but information on relative abundance in bird communities is lacking. Currently no published description of a Guatemalan cloud forest bird community, treating all species, is widely available. Komar (2002) provided the first relative abundance description for a northern Central American cloud forest bird community at Cerro Montecristo $\left(14^{\circ} 26^{\prime} \mathrm{N} 89^{\circ} 21^{\prime} \mathrm{W}\right.$ ), in northern El Salvador. An inventory is available for the
El Triunfo cloud forest $\left(15^{\circ} 39^{\prime} \mathrm{N} 92^{\circ} 48^{\prime} \mathrm{W}\right)$ in Chiapas, Mexico, without detailed data on relative abundance (Parker III et al. 1976, Gómez de Silva et al. 1999). Unpublished data are available from the Sierra de las Minas $\left(15^{\circ} 05^{\prime} \mathrm{N}\right.$ 8957’ W), department El Progreso, Guatemala (Robbins and Dowell 1992, Ponciano 1998, Eisermann 1999, Nájera 2004) and the Montaña Yalijux (15'23' N 9004' W), Alta Verapaz in Guatemala (Renner 2003, pers. obs.). The cloud forests at all sites cover a similar altitudinal range as the Caquipec forest at elevations of 2 000-2 $400 \mathrm{~m}$ (Montecristo: 2 000-2 $350 \mathrm{~m}$, El Triunfo: $1870-2450 \mathrm{~m}$, Sierra de las Minas and Yalijux: $2000-2500 \mathrm{~m}$ ). To compare the most common species between the five sites, we use the species detected by Komar (2002) at least once in a four-hour period of 'intensive searches' at Montecristo; the species which were labeled 'numerous' in Gomez de Silva et al. (1999) or 'common' in Parker III et al. (1976) in El Triunfo; the species with a dominance $>1 \%$ in Yalijux (Renner 2003); and the species classified as 'common' and 'fairly common' in Sierra de las Minas (Nájera 2004). From our data from the Montaña Caquipec we classify species with a relative abundance value of $>0.28$ per $100 \mathrm{~m}$ of transect as common, which equals 1 bird per $360 \mathrm{~m}$ of transect sampled (4 hours) and is therefore comparable with the effort of Komar (2002). Five of the most common species have been recorded at all sites: Rufous-browed Wren (Troglodytes rufociliatus), Gray-breasted Wood-Wren (Henicorhina leucophrys), Ruddy-capped Nightingale-Thrush (Catharus frantzii), Golden-browed Warbler

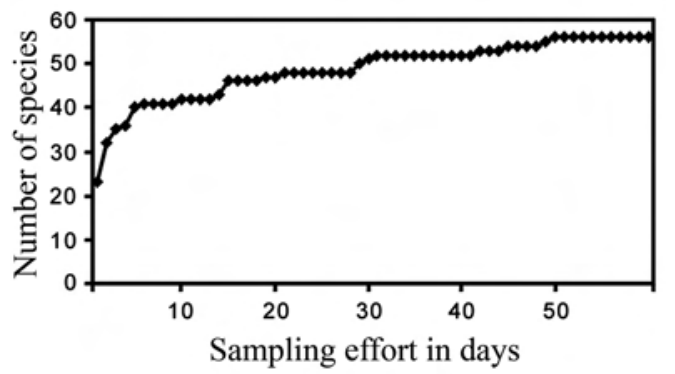

Fig. 2. Species accumulation during transect counts. 
(Basileuterus belli), and Common BushTanager (Chlorospingus ophthalmicus). The Spotted Nightingale-Thrush (Catharus dryas), classified as common in Montecristo and El Triunfo, was not recorded or was classified as vagrant in all of the Guatemalan high-altitude cloud forest sites (one observation at Caquipec, P. Kaestner pers. comm., Robbins and Dowell 1992, Renner 2003). In Alta Verapaz, this species is common at lower elevations $(<1500 \mathrm{~m}$, Eisermann, unpub. data). Although the cloud forest avifauna of northern Central America (eastern Chiapas, Guatemala, El Salvador and Honduras) has been described as similar based on regional species lists (Hernández-Baños et al. 1995), there are differences between the five cloud forest sites. Figure 3 shows the similarity of the bird communities of Caquipec, Yalijux, Sierra de las Minas, El Triunfo and Montecristo, taking into account all species recorded within the forest except NearcticNeotropical migrants and overhead transients. Yalijux is located $\sim 11 \mathrm{~km}$ to the east of Caquipec. Both sites are connected by a narrow corridor of cloud forest, and bird communities are very similar. Higher dissimilarity seems to result from longer distances between sites. The Sierra de las Minas is located at a distance of $\sim 35 \mathrm{~km}$ from Caquipec, separated by the Polochic valley. An interchange between bird populations of both sites has been observed on the Resplendent Quetzal (Pharomachrus mocinno), which moved apparently from the Sierra de las Minas eastwards to the Sierra de Chuacús and from there to Caquipec and Yalijux (Paiz 1996). The Sierra de los Cuchumatanes is an altitudinal corridor between Caquipec and El Triunfo, which is $\sim 270 \mathrm{~km}$ away. The high dissimilarity of the bird community at Montecristo (Fig. 3, 135 km from Caquipec), is probably caused by isolation from the ChiapasGuatemalan highlands. Current descriptions of northern Central American cloud forest sites are insufficient to explain differences in the composition of the bird communities. All papers present data from short-term studies, thus annual or long-term population fluctuations are unknown.

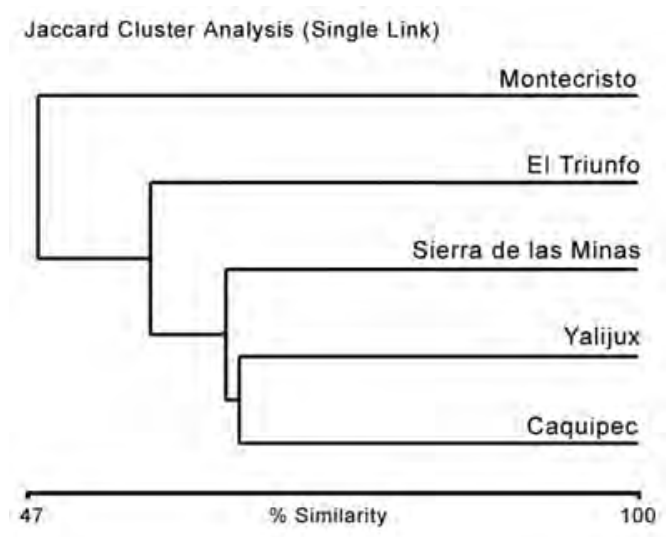

Fig. 3. Cluster analysis based on presence / absence of bird species in five northern Central American high-altitude cloud forests, performed with software Biodiversity Professional (McAleece et al. 1997). Data for El Triunfo from Parker III et al. (1976) and Gómez de Silva et al. (1999), for Montecristo from Komar (2002); for Sierra de las Minas from Robbins and Dowell (1992), Ponciano (1998), Eisermann (1999) and Nájera (2004); for Sierra Yalijux from Renner (2003) and pers. obs.

Long-term monitoring of bird populations and their habitats is necessary in order to identify factors that affect populations.

We observed a remarkably high relative abundance of the Amethyst-throated Hummingbird (Lampornis amethystinus) at Caquipec (0.99 birds per $100 \mathrm{~m}$ transect, dominance $5.9 \%$, Tab. 2). In Montecristo, no hummingbird was recorded with a dominance $>5 \%$ of all individuals (data from Komar 2002). In South American cloud forests, hummingbirds have been recorded within the most abundant species. Poulsen and Krabbe (1998) recorded three hummingbird species at some study sites above $3000 \mathrm{~m}$ with more than 5\% dominance. The highest dominance was recorded for the Tyrian Metaltail (Metallura tyrianthina) at the Chaucha site with $11.6 \%$. Terborgh (1977) has shown that the dominance of the nectarivorous guild increases toward higher elevations and attributed this phenomenon to a more abundant and more constant supply of food resources in higher altitudes and a lack of food resources for other species. 


\section{Human Impact}

Because there are no historical data available on the bird community of the Montaña Caquipec, the human impact on it is difficult to assess. Thirty nine species were recorded exclusively in open habitat and indicate increased species richness throughout the whole area, because this kind of habitat did not exist in the research area before human settlement. We assume that human activity has had some negative effects on species richness through the reduction of forest size and hunting. The Horned Guan (Oreophasis derbianus), for example, was not found in the current study. This endemic cloud forest cracid is very sensitive to disturbance, especially hunting (Howell and Webb 1995, González-García et al. 2001), and was still reported for the region of Cobán until the first half of the 20th century (Hellmayr and Conover 1942). Unfortunately no exact geographic data are available, but these reports are probably from Caquipec, since this mountain range is accessible by road since long and it is the highest mountain in Alta Verapaz. Thiollay (1984) and Peres (2000) have demonstrated that even low intensity hunting can heavily affect game populations and their natural predators, which could explain the absence of the Horned Guan, and the low abundance of the Highland Guan (Penelopina nigra) in the study area (Table 2).

In other tropical regions, little similarity was found between commercially exploited forest and pristine forest (Newmark 1991, Thiollay 1992, Mason 1996). In Caquipec, the high degree of similarity between the bird communities of undisturbed and disturbed forest indicates that the subsistence use of forest resources by Q'eqchi' communities may have low impact on the overall species composition.

\section{Conservation}

The Northern Central Amerian Highland, which includes the mountains of Chiapas, Guatemala, El Salvador and Honduras, is a recognized endemic bird areas (Bibby et al. 1992b, Stattersfield et al. 1998, Brown and Kappelle 2001). In the current study, 42 $(\sim 30 \%)$ of the recorded species are endemic to Mesoamerica and 14 species ( 10\%) are endemic to the Northern Central American Highlands. Twelve species of the latter group were recorded in cloud forest (Tables 2 and 3). Four species recorded at Caquipec are listed in the Red List of globally threatened species (BirdLife International 2004): Highland Guan (Penelopina nigra: Near Threatened), Resplendent Quetzal (Pharomachrus mocinno: Near Threatened), Pink-headed Warbler (Ergaticus versicolor: Vulnerable), and the migratory Golden-cheeked Warbler (Dendroica chrysoparia: Endangered). The high percentage species with a restricted range and the presence of four globally threatened species identify the Montaña Caquipec as an important area for bird conservation and emphasize the high importance of Guatemalan high-altitude cloud forests for conservation. Conservation efforts in these forests are insufficient in Guatemala. Although the Guatemalan system of protected areas covers almost $30 \%\left(31930 \mathrm{~km}^{2}\right)$ of the country (CONAP 2003), only $\sim 235 \mathrm{~km}^{2}$ are cloud forests ( $7 \%$ of protected areas). These include the Sierra de las Minas, some smaller areas in the southern volcanic belt, the 'Biotopo del Quetzal' in Baja Verapaz and areas in the western highlands. Humid montane forests of the northernmost mountain chain of Guatemala are underrepresented in the system of protected areas. In the northern part of the department of Alta Verapaz there are only 5 protected areas with cloud forest. Their sizes are rather small, ranging from 48 to 1366 ha, for a total of $26 \mathrm{~km}^{2}$ (CONAP 2003). We assume that such small areas will not support viable populations of many bird species. Altitudinal migration has been reported for many cloud forest bird species (Powell and Bjork 1994, Howell and Webb 1995, Paiz 1996, Winker et al. 1997). This has led to the recognition that an extension of conservation activities along the altitudinal gradient is essential for the effective conservation of many species. Conservation activities need to be extended into rural communities (Islebe and 
Véliz 2001). Various local NGOs have been active at Caquipec by supporting indigenous communities with agricultural and ecotourism projects, in order to generate alternative income and reduce the rate of deforestation (Schulz and Unger 2000). At present, we are unable to evaluate the impact of alternative forest use, such as tourism, on the habitat quality of the forest. A long-term monitoring is needed to be able to evaluate population trends and human impact. Data provided here will be useful baseline data for further research.

\section{ACKNOWLEDGMENTS}

The period of familiarization with the bird voices would have been much longer without the invaluable support of Amy Seglund and Shawn Conner during an introductory field trip. We are grateful to the staff of BIDAS / Proyecto Eco-Quetzal (Cobán, Alta Verapaz) for its technical support and to David Unger for constructive discussion during the field work. Thanks to the Q'eqchi' indigenous people of the community of Chicacnab for their kind cooperation. We thank Jürgen Engel for statistical advice. We appreciate critical comments on the manuscript by an unknown reviewer and Claudia Avendaño, and the improvements in English usage made by Erick Baur through the Association of Field Ornithologists' program of editorial assistance. Special thanks to Peter, Gisela and Käthe Eisermann for their financial support.

\section{RESUMEN}

Las alturas del norte de Centroamérica han sido reconocidas como región de aves endémicas, pero se conoce poco sobre las comunidades de aves en bosques nubosos de Guatemala. De 1997 a 2001 se han detectado 142 especies de aves entre 2000 y $2400 \mathrm{msnm}$ en el bosque nuboso y áreas agrícolas en la Montaña Caquipec (Alta Verapaz, Guatemala). El patrón de la comunidad de aves se describe por medio de censos en transectos de línea. Combinando los datos de censos en bosque prístino y bosque perturbado se concluyó que Henicorhina leucophrys es la especie más abundante, seguida en orden descendente por Chlorospingus ophthalmicus, Zimmerius vilissimus, Empidonax flavescens, Catharus frantzii y Lampornis amethystinus. El índice de Sørensen de 0.85 entre bosque prístino y bosque perturbado indica un impacto relativamente bajo de la población humana local. El $\sim 27 \%$ de todas las especies encontradas fueron aves migratorias neárticas, siendo la más abundante Wilsonia pusilla. La Montaña Caquipec es un área importante para la conservación de aves, lo cual es indicado por la presencia de cuatro especies incluidas en la Lista Roja de IUCN (Penelopina nigra, Pharomachrus mocinno, Ergaticus versicolor, Dendroica chrysoparia) y de 42 especies endémicas de Mesoamérica, de las cuales 14 son endémicas de las alturas norteñas de Mesoamérica. Estos resultados servirán como base para un monitoreo a largo plazo.

Palabras clave: Aves, bosque nuboso, conservación, Guatemala, migración, Neartico-Neotrópico migrants, riqueza de especies.

\section{REFERENCES}

AOU. 1998. The American Ornithologists' Union Check-list of North American Birds. American Ornithologists' Union, Washington D.C. 829 p.

Banks, R.C., C. Cicero, J.L. Dunn, A.W. Kratter, P.C. Rasmussen, J.V. Remsen, Jr., J.A. Rising \& D.F. Stotz. 2003. Forty-fourth supplement to the American Ornithologists' Union check-list of North American birds. Auk 120: 923-931.

Banks, R.C., C. Cicero, J.L. Dunn, A.W. Kratter, P.C. Rasmussen, J.V. Remsen, Jr., J.A. Rising \& D.F. Stotz. 2004. Forty-fifth supplement to the American Ornithologists' Union check-list of North American birds. Auk 121: 985-995.

Begon, M., J.L. Harper \& C. Townsend. 1990. Ecology - individuals, populations, communities. Blackwell, Oxford. 960 p.

Bibby, C.J., N.D. Burgess \& D.A. Hill. 1992a. Bird census techniques. Academic, London. 257 p.

Bibby, C.J., N.J. Collar, M.J. Crosby, M.F. Heath, C. Imboden, T.H. Johnson, A.J. Long, A.J. Stattersfield, \& S.J. Thirgood. 1992b. Putting biodiversity on the map: priority areas for global conservation. International Council for Bird Preservation, Cambridge, United Kingdom. 90 p.

BirdLife International. 2004. Threatened birds of the world 2004. CD-Rom. BirdLife International, Cambridge, United Kingdom.

Brown, A.D. \& M. Kappelle. 2001. Introducción a los bosques nublados del neotrópico: una síntesis 
regional. p. 25-40. In M. Kappelle \& A.D. Brown (eds.). Bosques nublados del neotrópico. Instituto Nacional de Biodiversidad, Santo Domingo de Heredia, Costa Rica.

CONAP. 2003. Informe nacional de areas protegidas de Guatemala. Concejo Nacional de Areas Protegidas, Presidencia de la República de Guatemala, Guatemala. 37 p.

DeGraaf, R.M. \& J.H. Rappole. 1995. Neotropical miratory birds: natural history, distribution, and population change. Cornell University, Ithaca, New York. 676 p.

Dobson, A.P. 1996. Conservation and Biodiversity. Scientific American Library, Freeman, New York. 264 p.

Doumenge, C., D. Gilmour, M.R. Pérez \& J. Blockhus. 1995. Tropical montane cloud forests: conservation status and management issues. pp. 24-37 In L.S Hamilton, J.O. Juvik \& F.N. Scatena (eds.) Tropical montane cloud forest. Springer, New York.

Engel, J. 1998. SSS. Rubisoft Software, Eichenau, Germany.

Eisermann, K. 1999. Avifaunistisch-ökologische Untersuchungen in einer Nebelwaldregion Guatemalas als Grundlage für die Entwicklung eines Biomonitoringprogramms. Thesis, Univ. of Applied Sciences, Eberswalde, Germany. 164 p.

FAO. 2003. State of the world's forests 2003. Food and Agriculture Organization of the United Nations, Rome. 168 p.

Gómez de Silva, H.G., F. González-García \& M.P. CasillaTrejo. 1999. Birds of the upper cloud forest of El Triunfo, Chiapas, Mexico. Ornitol. Neotrop. 10: 1-26.

González-García, F., D.M. Brooks \& S.D. Strahl. 2001. Estado de conservación de los Cracidos en Mexico y Centro América. pp. 1-50 in D.M. Brooks \& F. González-García (eds.). Cracid ecology and conservation in the new millenium. Misc. Pub. Houston Mus. Nat. Science, Publ. 2.

Hamilton, L.S., J.O. Juvik \& F.N. Scatena. 1995. The Puerto Rico tropical cloud forest symposium: introduction and workshop synthesis. pp. 1-23 In L.S Hamilton, J.O. Juvik \& F.N. Scatena (eds.) Tropical montane cloud forest. Springer, New York.

Hellmayr, C.E. \& B. Conover. 1942. Catalogue of birds of the Americas and the adjacent islands. Part 1. Field Mus. Nat. His. 13, pt. 1, no. 1 .

Hernández-Baños, B.E., A.T. Peterson, A.G. NavarroSigüenza \& P. Escalante-Pliego. 1995. Bird faunas of the humid montane forests of Mesoamerica: biogeographic patterns and priorities for conservation. Bird Conserv. Int. 5: 251-277.
Howell, S.N.G. \& S. Webb. 1995. A guide to the birds of Mexico and northern Central America. Oxford Univ., New York. 851 p.

Islebe, G.A. \& M.E. Véliz Pérez. 2001. Guatemala. p. 231-241 In M. Kappelle \& A.D. Brown (eds.). Bosques nublados del neotrópico. Instituto Nacional de Biodiversidad. Santo Domingo de Heredia, Costa Rica.

Krebs, C.J. 1999. Ecological methodology. Benjamin/ Cummings, Menlo Park, California. 624 p.

Kremen, C., A.M. Merenlender, \& D.D. Murphy. 1994. Ecological monitoring: a vital need for integrated conservation and development programs in the tropics. Conserv. Biol. 8: 388-397.

Komar, O. 2002. Birds of Montecristo National Park, El Salvador. Ornitol. Neotrop. 13: 167-193.

Lehner, P.N. 1978. Handbook of ethological methods. Garland STPM, New York. 403 p.

Long, A.J. 1995. The importance of tropical mountain cloud forests for endemic and threatened birds. pp. 79-105 In L. S. Hamilton, J.O. Juvik, \& F. N. Scatena (eds.) Tropical montane cloud forest. Springer, New York.

MAGA. 2002. Atlas de Guatemala. CD-Rom. Ministerio de Agricultura, Ganadería y Alimentación, Guatemala.

Mason, D. 1996. Responses of Venezuelan understory birds to selective logging, enrichment strips, and vine cutting. Biotropica 28: 296-309.

Magurran, A.E. 1991. Ecological diversity and its measurement. Chapman and Hall, London. 179 p.

Mühlenberg, M. 1993. Freilandökologie. Quelle \& Meyer, Heidelberg, Germany. 512 p

Nájera, A. 2004. Diversidad y estructura de la avifauna en el bosque nuboso primario de Albores, Sierra de las Minas, Guatemala. Thesis, Univ. del Valle de Guatemala, Guatemala. 77 p.

Navarro S., A.G. 1992. Altitudinal distribution of birds in the Sierra Madre del Sur, Guerrero, Mexico. Condor 94: 29-39.

Newmark, W.D. 1991. Tropical forest fragmentation and the local extinction of understory birds in the eastern Usambara Mountains, Tanzania. Conserv. Biol. 5: 67-78.

Paiz, M.C. 1996. Migraciones estacionales del Quetzal (Pharomachrus mocinno mocinno de la Llave) en la Sierra de las Minas y sus alrededores: implicaciones para su conservación. Thesis, Univ. del Valle de Guatemala, Guatemala. 109 p. 
Parker III, T.A., S. Hilty \& M. Robbins. 1976. Birds of the El Triunfo cloud forest, Mexico, with notes on the Horned Guan and other species. American Birds 30: 779-782.

Peres, C.A. 2000. Effects of subsistence hunting on vertebrate community structure in Amazonian forests. Conserv. Biol. 14: 240-253.

Primack, R.B. 1993. Essentials of conservation biology. Sinauer, Sunderland, Massachusetts. 375 p.

Primack, R.B. \& R.T.Corlett. 2005. Tropical Rain Forests - An Ecological and Biogeographical Comparison. Blackwell, Oxford, United Kingdom. 336 p.

Poulsen, B.O. \& N. Krabbe. 1998. Avifaunal diversity of five high-altitude cloud forests on the Andean western slope of Ecuador: testing a rapid assessment method. J. Biogeography 25: 83-93.

Ponciano, J.M. 1998. Comunidades de aves en función de la distancia con la frontera agrícola en la Sierra de las Minas, Guatemala. Thesis, Univ. del Valle de Guatemala, Guatemala. 118 p.

Powell, G.V.N. \& R.D. Bjork. 1994. Implication of altitudinal migration for conservation strategies to protect tropical biodiversity: A case study of the Quetzal (Pharomachrus mocinno) at Monte Verde, Costa Rica. Bird Conserv. Int. 4: 161-174.

Renner, S. 2003. Structure and diversity of cloud forest bird communities in Alta Verapaz, Guatemala, and implications for conservation. Diss. Thesis, GeorgAugust-Univ. Göttingen, Germany. 101 p.

Rice, W.R. 1989. Analyzing tables of statistical tests. Evolution 43: 223-225.

Richards, P.W. 1996. The tropical rain forest. Cambridge University, Cambridge, United Kingdom. 575 p.

Robbins, C.S. \& B.A. Dowell. 1992. Report on bird survey at Sierra de las Minas, March 1992. Patuxent Wildlife Research Center. U.S. Fish \& Wildlife Service, Laurel, Maryland. 22 p.

Schulz, U. \& D. Unger. 2000. Integration von Landnutzung und Regenwaldschutz: eine Fallstudie aus Guatemala. p. 94-105. In R. Detsch (ed.) Aktuelle Strömungen in Landschaftsnutzung und Naturschutz. Wissenschaft $\&$ Technik, Berlin. 306 p.
Stattersfield, A.J., M.J. Crosby, A.J. Long \& D.C. Wege. 1998. Endemic bird areas of the world: priorities for biodiversity conservation. BirdLife Conservation Series No. 7. BirdLife International, Cambridge, United Kingdom. 864 p.

Stiles, F.G. \& A.F. Skutch. 1989. A guide to the birds of Costa Rica. Comstock/Cornell Univ., Ithaca, New York. $511 \mathrm{p}$.

Stotz, D.F., J.W. Fitzpatrick, T.A. Parker III, \& D.K. Moskovits. 1996. Neotropical birds: ecology and conservation. Univ. of Chicago, Chicago. 481 p.

Terborgh, J. 1977. Bird species diversity on an Andean elevational gradient. Ecology 58: 1007-1019.

Thiollay, J.-M. 1984. Raptor community structure of a primary rain forest in French Guiana and effects of human hunting pressure. J. Raptor Res. 18: 117-122.

Thiollay, J.-M. 1992. Influence of selective logging on bird species diversity in a Guianan rain forest. Conserv. Biol. 6: 47-63.

Wege, D.C. \& A.Long. 1995. Key areas for threatened birds in the Neotropics. Birdlife Conservation Series No. 5. Birdlife International, Cambridge, United Kingdom. 311 p.

Weyl, R. 1980. Geology of Central America. Borntraeger, Berlin und Stuttgart. $371 \mathrm{p}$.

Wilson, E.O. 1992. The Diversity of Life. Belknap, Harvard Univ., Cambridge, Massachusetts.

Winker, K., P. Escalante, J.H. Rappole, M.A. Ramos, R.J. Oehlenschlager \& D.W. Warner. 1997. The evolution and conservation of Wetmore's BushTanager: periodic migration and lowland forest refugia in a "sedentary" Neotropical bird. Conserv. Biol. 11: 692-697.

\section{INTERNET REFERENCE}

McAleece, N., J. Lambshead, G. Patterson \& J. Gage. 1997. Biodiversity Professional. The Natural History Museum and The Scottish Association For Marine Science. (available online at http://www.sams.ac.uk, site accessed 7 June 2005). 